\title{
PERANCANGAN APLIKASI PENERIMAAN PESERTA DIDIK BARU PADA SEKOLAH MENENGAH PERTAMA (SMP) FATAHILLAH KABUPATEN BEKASI
}

\author{
Rani Desy Faddillah ${ }^{1}$, Dwi Yulistyanti ${ }^{2}$, Rudi Hermawan ${ }^{3}$ \\ 1,2,3 Informatika, Teknik dan Ilmu Komputer, Universitas Indraprasta PGRI \\ Email: ${ }^{1}$ ranydfadillah@gmail.com
}

\begin{abstract}
The development of information technology in all types of fields, one of which is in the field of education where the school can utilize the information technology to facilitate school performance, especially at the time of admission of new students. The Design of New Student Acceptance Applications at the Junior High School (SMP) Fatahillah Bekasi Regency was made aiming to make it easier to manage the data of new student admissions so that the process of presenting data relating to the data of new student admissions can be completed quickly, precisely and accurately. The research method used in designing this application is to use the research and development method. In addition, the system used in this study is the waterfall system. In this system, there are several steps that must be done including analyzing the needs, design, implementation and coding as well as testing. The design of the New Student Acceptance Application was created with the support of the Java programming language and MYSQL and XAMPP databases. From the results of the research that has been done, it is found that the application of acceptance of new students can meet the needs in a process of presenting data for new students that is fast, precise and accurate and effective and efficient.
\end{abstract}

Keywords: Application design, Student acceptance, Java, MYSQL.

\begin{abstract}
Abstrak. Berkembangnya teknologi informasi pada semua jenis bidang, salah satunya pada bidang pendidikan dimana pihak sekolah dapat memanfaatan teknologi informasi tersebut untuk memudahkan kinerja sekolah, khususnya pada saat penerimaan peserta didik baru. Perancangan Aplikasi Penerimaan Peserta Didik Baru pada Sekolah Menengah Pertama (SMP) Fatahillah Kabupaten Bekasi dibuat bertujuan untuk mempermudah dalam mengelola data penerimaan peserta didik baru agar proses penyajian data yang berkenaan dengan data penerimaan peserta didik baru dapat terselesaikan dengan cepat, tepat dan akurat. Metode penelitian yang digunakan dalam perancangan aplikasi ini adalah dengan menggunakan metode research and development. Selain itu, sistem yang digunakan pada penelitian ini adalah sistem waterfall. Pada sistem ini, terdapat beberapa tahapan yang harus dilakukan diantaranya menganalisa kebutuhan, perancangan, implementasi dan pengkodean serta pengujian. Perancangan Aplikasi Penerimaan Peserta Didik Baru ini tercipta dengan dukungan bahasa pemrograman Java serta database MYSQL dan XAMPP. Dari hasil penelitian yang telah dilakukan, diperoleh bahwa aplikasi penerimaan peserta didik baru dapat memenuhi kebutuhan dalam suatu proses penyajian data peserta didik baru yang cepat, tepat dan akurat serta efektif dan efisien.
\end{abstract}

Kata Kunci: Perancangan aplikasi, Penerimaan peserta didik, Java, MYSQL.

\section{Pendahuluan}

Peran teknologi informasi dan komunikasi saat ini semakin memainkan perannya dengan berkembang cepat yang menjadi suatu kebutuhan. Seiring dengan perkembangan teknologi, banyak Sekolah Menengah Pertama (SMP) yang sudah memanfaatkannya sebagai wadah untuk pelayanan kepada peserta didik maupun orangtua. Kemudahan yang diperoleh terasa lebih nyata dan juga tidak ketinggalan zaman dengan sekolah lainnya khususnya Sekolah Menengah Pertama (SMP) di Kabupaten Bekasi yang sudah memanfaatkan teknologi dalam pelayanan kepada peserta didik, maka sangatlah penting bagi Sekolah Menengah Pertama mempunyai sebuah perancangan aplikasi untuk pelayanan peserta didik baru dalam mendapatkan informasi yang bersangkutan dengan sekolah.

Berkembangnya teknologi informasi pada semua jenis bidang, salah satunya pada bidang pendidikan yaitu dengan membuat sekolah memanfaatkan teknologi informasi untuk memudahkan kinerja sekolah, khususnya pada saat ajaran baru tiba yaitu penerimaan peserta didik baru. 
Penelitian terhadap penerimaan siswa baru di sekolah dengan memanfaatkan perkembangan teknologi telah banyak dilakukan, diantaranya adalah penelitian yang telah dilakukan oleh Suherni. S., dkk (2017) dengan membuat aplikasi pendaftaran dan penerimaan siswa baru di SMK Negeri 1 Rupa berbasis web dan SMS Gateway(Suherni, Rubiati, 2017). Penelitian lainnya juga telah dilakukan oleh Amin, R., (2017) dengan membuat rancang bangun sistem informasi penerimaan siswa baru pada SMK Budhi Warman 1 Jakarta berbasis web(Ruhul Amin, 2017).

SMP Fatahillah merupakan sekolah menengah pertama di Kabupaten Bekasi dimana sekolah ini siap mengemban amanah untuk membentuk kader generasi yang konsisten sesuai dengan tujuan pendidikan yaitu membentuk insan yang beriman, bertaqwa, berilmu dan berakhlak mulia (IMTAQ). Proses penerimaan peserta didik baru di Sekolah Menengah Pertama (SMP) Fatahillah Kabupaten Bekasi sudah menggunakan komputer, namun penggunaan komputer yang dimaksud digunakan hanya untuk membuat formulir dengan menggunakan Ms.Excel dan Ms.Word saja. Untuk proses pendaftaran peserta didik masih menggunakan cara manual dimana formulir pendaftaran diisi oleh calon peserta didik baru, kemudian diberikan kepada bagian kemahasiswaan dan staff tata usaha yang bertugas menjadi panitia. Untuk selanjutnya panitia membuat data laporan. Proses tersebut menjadikan media penyimpanan data peserta didik baru masih berupa kertas dan buku sehingga dokumen menjadi tidak aman dan kurang terjamin dalam penyimpanannya. Sehubungan dengan hal tersebut, perlu adanya sistem yang teraplikasi pada penerimaan peserta didik baru agar pendataan terkait informasi peserta didik menjadi lebih efektif dan efisien. Untuk mengatasi masalah tersebut, penulis membuat suatu perancangan aplikasi penerimaan peserta didik baru pada Sekolah Menengah Pertama (SMP) Fatahillah Kabupaten Bekasi.

\section{Tinjauan Pustaka}

\section{Perancangan}

Menurut Sommerville, 2011, p. 154, "proses perancangan perangkat lunak merupakan serangkaian kegiatan dan hasil yang berhubungan dengan perangkat lunak, yang bertujuan untuk dihasilkannya suatu produk perangkat lunak".

Berdasarkan pendapat yang dikemukakan, perancangan adalah serangkaian kegiatan yang bertujuan untuk suatu produk yang dihasilkan.

Menurut Sommerville (2011:154) dasar perancangan ialah sebagai berikut :

1. Penspesifikasikan Perangkat Lunak

2. Fungsionalitas perangkat lunak dan batasan operasinya harus didefinisikan.

3. Perancangan dan Implementasi Perangkat Lunak.

4. Perangkat lunak yang memnuhi persyaratan harus dibuat.

5. Pengevolusian perangkat lunak

6. Perangkat lunak harus dapat berkembang untuk menghadapi kebutuhan yang dapat berubah sewaktu-waktu.

\section{Sistem}

Menurut Mulyadi, 2011, "menjelaskan bahwa sistem merupakan sekelompok unsur yang erat berhubungan satu dengan yang lainnya, yang berfungsi bersama-sama untuk mencapai tujuan tertentu".

\section{Aplikasi}

Menurut Sutabri, 2012, p. 147, menjelaskan bahwa aplikasi adalah alat terapan yang difungsikan secara khusus dan terpadu sesuai kemampuan yang dimilikinya.

\section{Pemrograman Java}

Menurut Raharjo, 2012, menjelaskan bahwa “ java adaalah bahasa pemrograman yang dapat dijalankan diberbagai komputer termasuk telepon genggam. 
Berdasarkan dari pendapat yang dikemukakan diatas, dapat disimpulkan oleh peneliti bahwa java merupakan bahasa pemrograman $\mathrm{C}++$ yang mendukung aplikasi pada client dan server termasuk telepon genggam.

\section{MYSQL}

Menurut Arief, 2011, p. 154, MySQL adalah salah satu jenis database server yang sangat terkenal dan banyak digunakan untuk membangun aplikasi web yang menggunakan database sebagai sumber dan pengolahan data.

\section{XAMPP}

Menurut Madcoms, 2016, p. 148, dengan menggunakan xampp, tidak perlu menginstal aplikasiaplikasi secara satu persatu. Paket aplikasi perlu di extract dan diinstal terlebih dahulu dengan memilih jenis xampp sesuai dengan jenis operating system.

\section{Siswa}

Menurut Prasetyo, 2013, p. 7, siswa atau peserta didik adalah anggota masyarakat yang berusaha mengembangkan potensi diri melalui proses pembelajaran yang tersedia pada jalur, jenjang dan jenis pendidikan tertentu, mereka yang secara khusus diserahkan oleh kedua orang tuanya untuk mengikuti pembelajaran yang diselenggarakan di sekolah, dengan tujuan untuk menjadi manusia yang berilmu pengetahuan, berketerampilan, berpengalaman, berkepribadian, berakhlak mulia dan manidiri.

\section{Metode Penelitian}

Pada penelitian ini, metode yang digunakan adalah metode Research and Development (R\&D). Research and Development adalah metode penelitian yang digunakan untuk menghasilkan produk tertentu dan menguji keefektifan produk tersebut. Penelitian ini dilakukan sejak bulan Maret s.d Juni 2019.

\subsection{Metode Pengumpulan Data}

Terdapat beberapa metode pengumpulan data yang dilakukan oleh peneliti untuk mendapatkan informasi serta data-data sebagai penyempurnaan hasil dalam penelitian ini diantaranya:

\subsection{Metode Wawancara}

Peneliti melakukan wawancara dengan salah satu pihak sekolah pada saat melakukan penelitian.

\subsection{Metode Observasi}

Melakukan teknik pengumpulan data dengan diberikan beberapa dokumen mengenai sistem penerimaan peserta didik baru oleh SMP Fatahillah Kabupaten Bekasi.

\subsection{Studi Kepustakaan}

Pengumpulan informasi serta data-data diketahui dari kutipan buku, hasil laporan dan bahan yang lainnya berkaitan dengan penelitian ini. Dari sumber tersebut diambil teori-teori yang dijalankan dengan landasan menganalisa masalah yang ditemukan dalam penelitian.

\subsection{Langkah - Langkah Pengembangan Sistem}

Langkah awal yang dilakukan dalam pengembangan sistem pada penelitian ini adalah dengan menentukan model sistem yang akan digunakan. Model sistem yang digunakan adalah sistem waterfall. Model sistem menuntut cara yang teratur dari suatu rangkaian yang mendekati perkembangan software, dimulai dengan suatu tingkatan kemajuan melalui analisis, perancangan, pengkodean, pengujian, serta pemeliharaan model tersebut. Sistem tersebut dapat dilihat pada Gambar 1. 


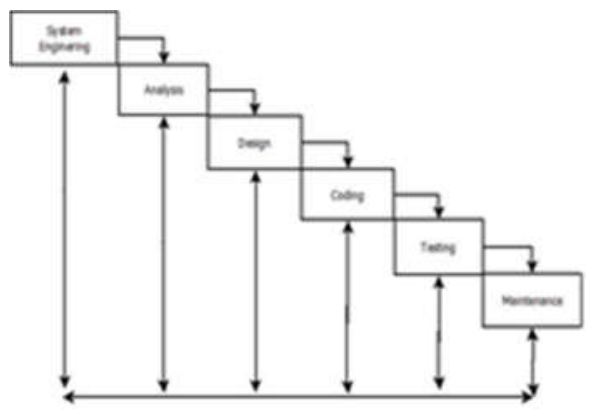

Gambar 1. Metode Waterfall

Sumber : (Sutanta, 2011)

\section{Hasil Penelitian}

Aturan sistem yang diusulkan pada Penerimaan Peserta Didik Baru pada Sekolah Menengah Pertama (SMP) Fatahillah Kabupaten Bekasi adalah sebagai berikut:

a. Panitia sekolah menginput data penerimaan peserta didik baru menggunakan aplikasi yang telah dibuat.

b. Panitia memiliki akun tersendiri untuk mengoperasikan.

c. Dengan menggunakan akun panitia, maka panitia dapat mengetahui secara keseluruhan penerimaan peserta didik baru pada aplikasi penerimaan peserta didik baru dan dapat melakukan print untuk menjadikan suatu laporan data penerimaan peserta didik baru.

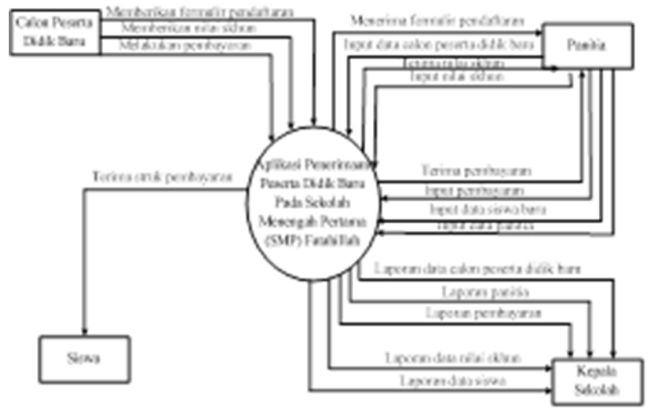

Gambar 2. Diagram Diagram Konteks yang Diusulkan

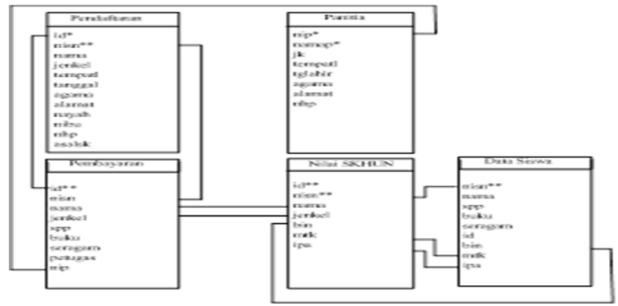

Gambar 3. Normalisasi Bentuk Ke-2 NF

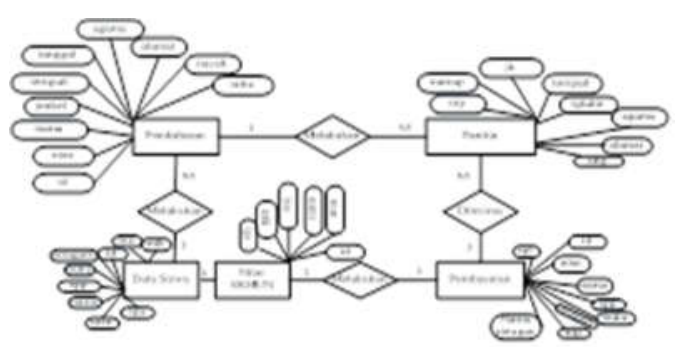


Gambar 4. Diagram ERD (Entity Relationship Diagram)

Berikut ini adalah rancang layar dari Perancangan Aplikasi Penerimaan Peserta Didik Baru Pada Sekolah Menengah Pertama (SMP) Fatahillah Kabupaten Bekasi :

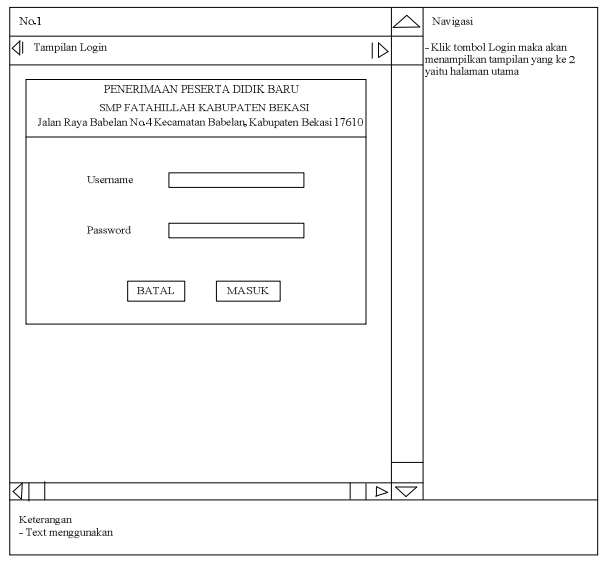

Gambar 5. Rancangan Layar Login

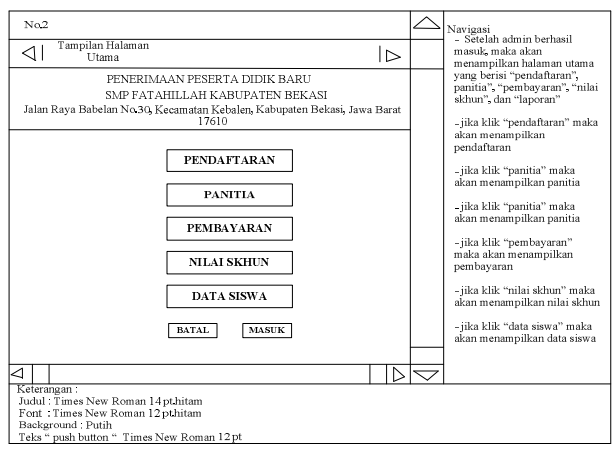

Gambar 6. Rancangan Layar Halama Utama

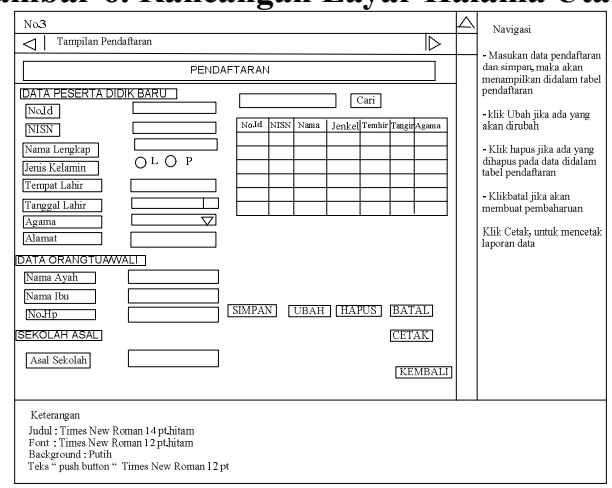

Gambar 7. Rancangan Layar Pendaftaran 


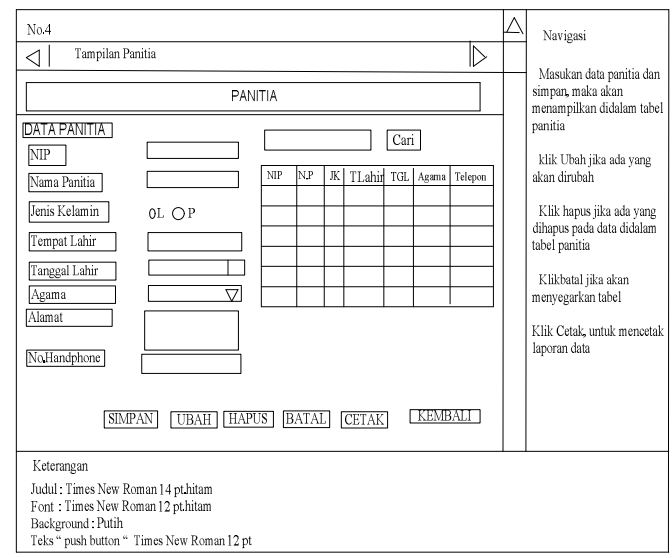

Gambar 8. Rancangan Layar Panitia

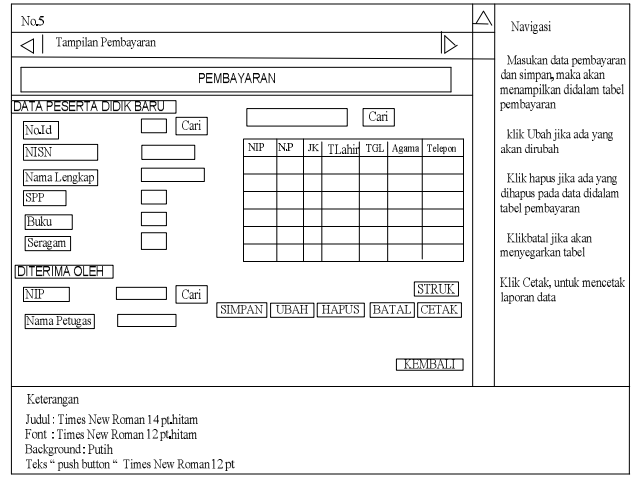

Gambar 9. Rancangan Layar Pembayaran

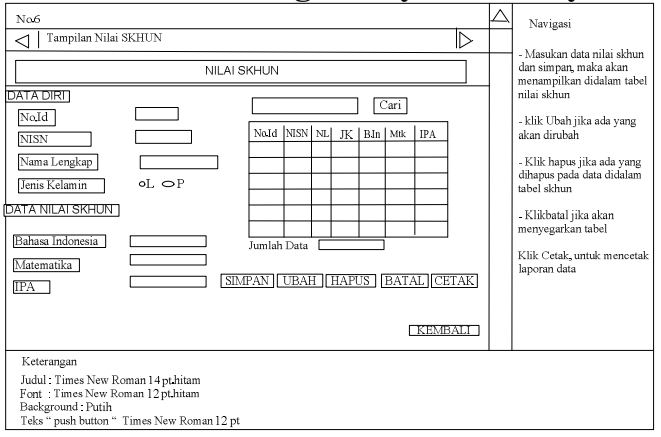

Gambar 10. Rancangan Layar Nilai SKHUN 


\section{Gambar 11. Rancangan Layar Data Siswa}

Selanjutnya penulis membuat aplikasi dengan menggunakan Java dan database mysql. Berikut ini adalah tampilan dari aplikasi penerimaan peserta didik baru pada Sekolah Menengah Pertama (SMP) Fatahillah Kabupaten Bekasi :

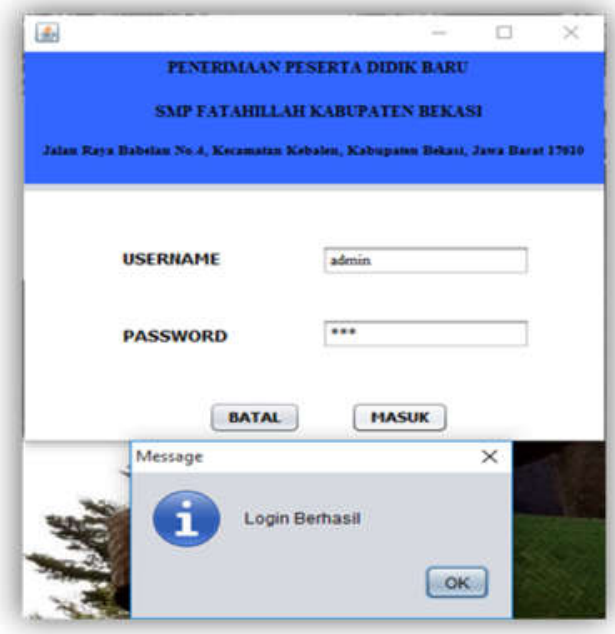

Gambar 12. Tampilan Login
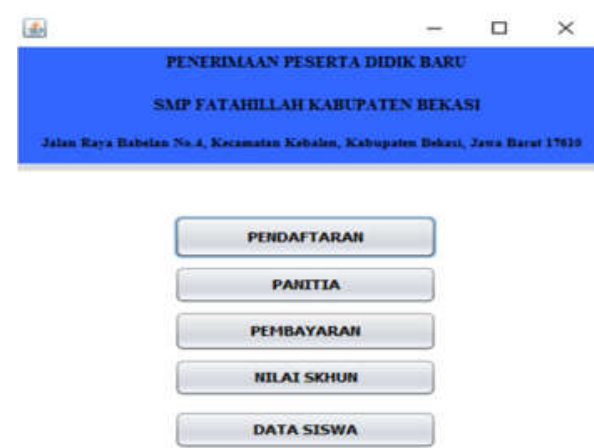

Tanggal : 01-Agustus-2019

$\operatorname{Jam}: 23: 20.33$

\section{Gambar 13. Tampilan Halaman Utama}




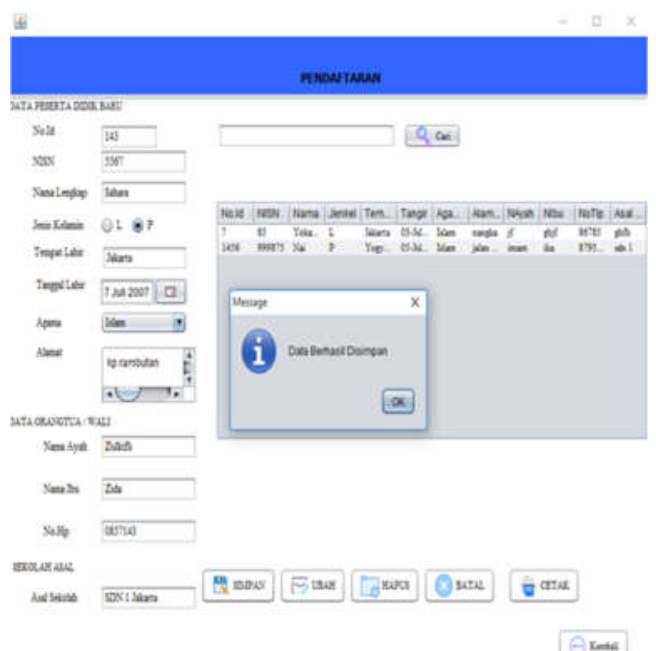

Gambar 14. Tampilan Pendaftaran

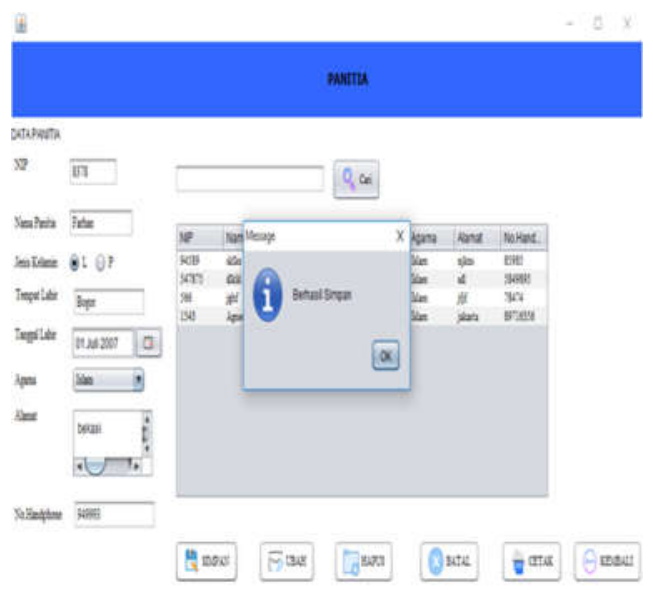

Gambar 15. Tampilan Panitia

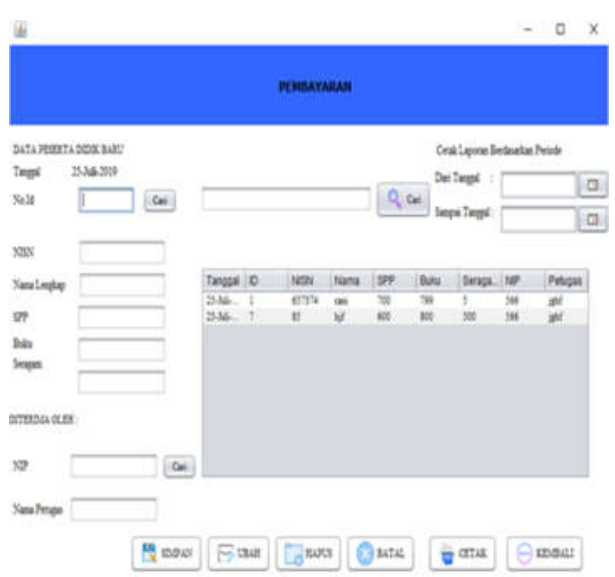

Gambar 16. Tampilan Pembayaran 


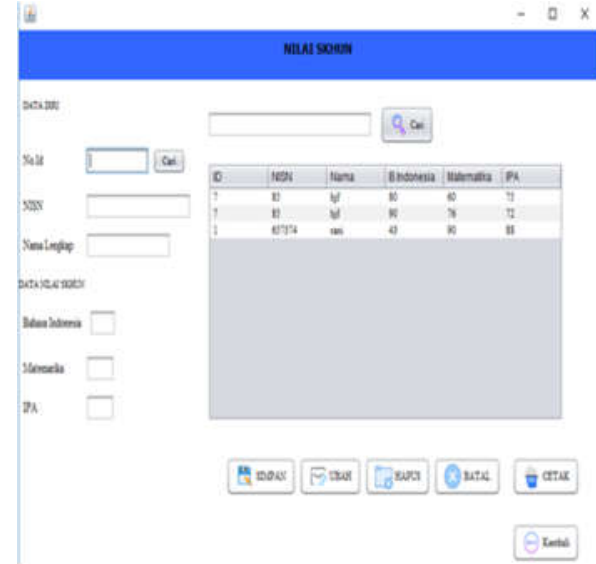

Gambar 17. Tampilan Nilai SKHUN

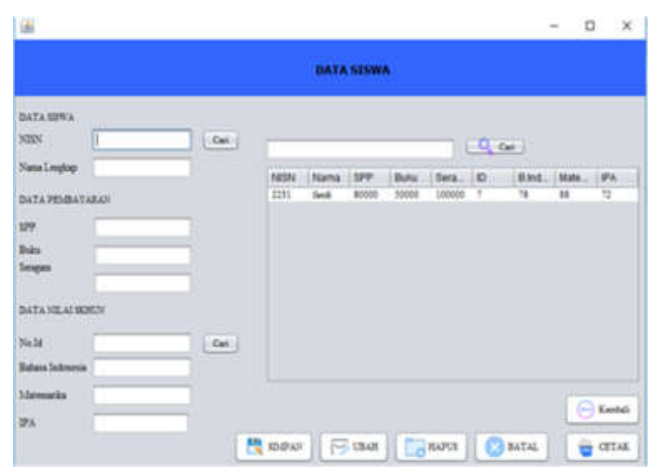

Gambar 18. Tampilan Data Siswa
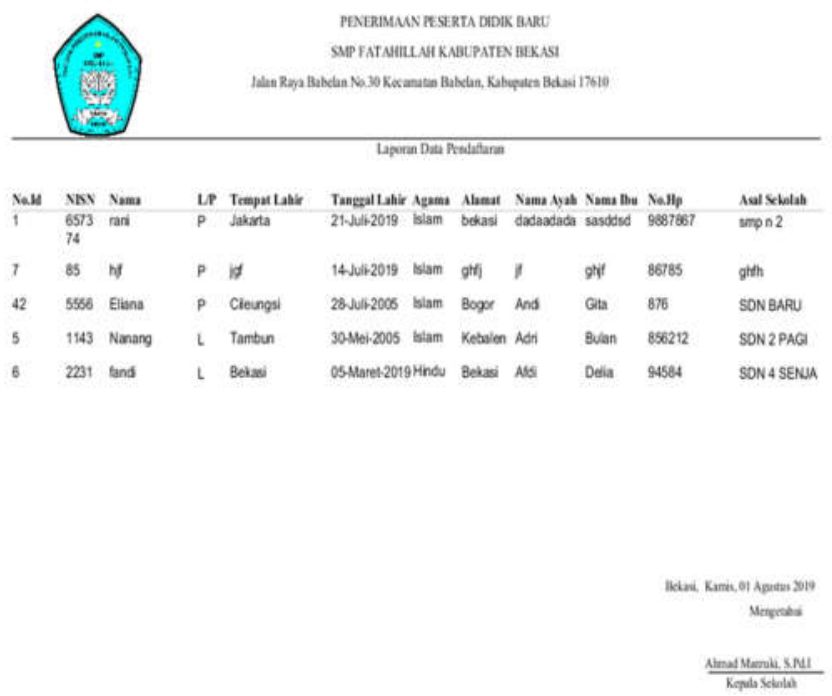

Gambar 19. Tampilan Laporan Pendaftaran 

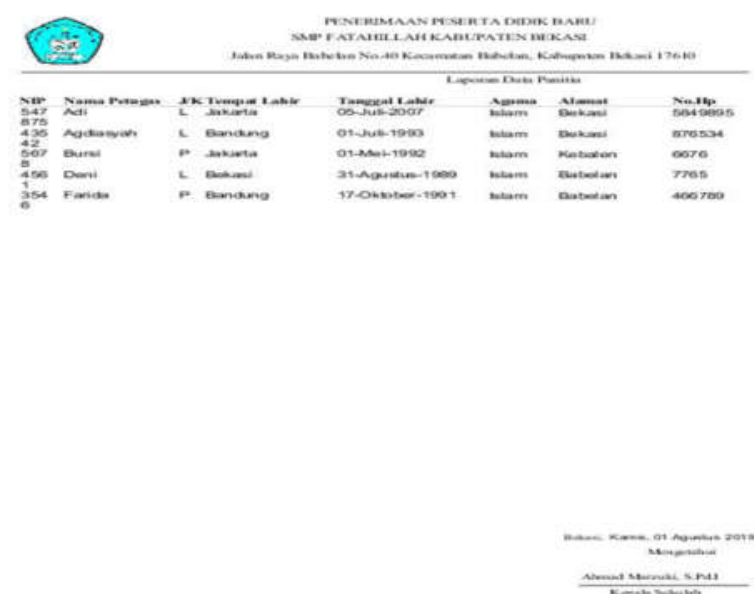

Gambar 20. Tampilan Laporan Panitia

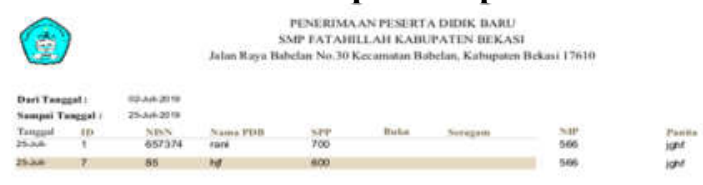

$\infty \quad \infty \infty$

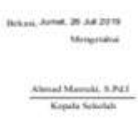

Gambar 21. Tampilan Laporan Pembayaran

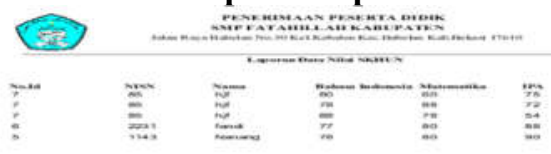

Gambar 22. Tampilan Laporan Nilai SKUN 

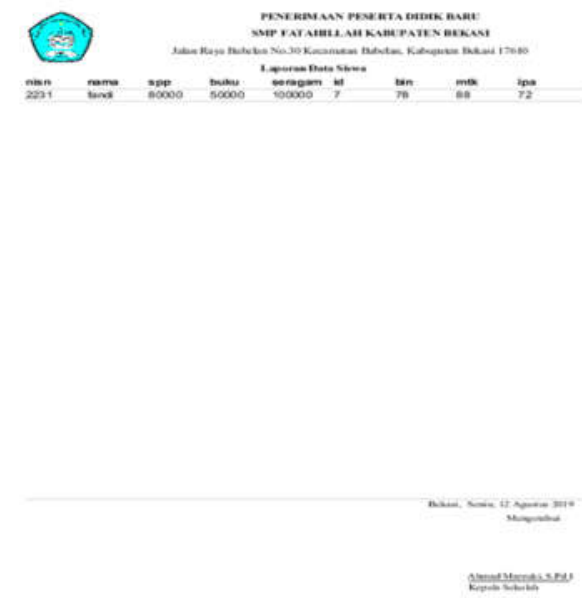

\section{Gambar 23. Tampilan Laporan Data Siswa}

\section{Kesimpulan dan Saran \\ 5.1 Kesimpulan}

Berdasarkan penelitian yang dilakukan oleh penulis, diperoleh simpulan sebagai berikut:

1. Dengan menggunakan sistem yang teraplikasi maka SMP Fatahillah mengalami peningkatan dalam menangani penerimaan pesserta didik baru.

2. Pengolahan data sistem penerimaan peserta didik baru menjadi lebih mudah efektif dan efisien. Serta terjamin keakuratan datanya karena sudah teraplikasi dengan baik pada yang di rancang oleh peneliti.

3. Pengawasan terhadap pelaksanaan kegiatan akan lebih mudah karena adanya laporan dan informasi kegiatan yang tepat waktu dan dapat disajikan setiap saat bila dibutuhkan.

\subsection{Saran}

1. Dalam meningkatkan efektivitas penerimaan peserta didik baru, peneliti menyarankan kepada pihak sekolah penerimaan.

2. Keamanan sistem perlu dijaga dengan cara mempercayakan pada personil yang bertanggung jawab.

\section{Referensi}

Arief, M. R. (2011). Pemrograman Web dinamis Menggunakan PHP dan MYSQL. Yogyakarta: Andi. Madcoms. (2016). Pemrograman PHP dan MYSQL Untuk Pemula (Yogyakarta, ed.). Andi.

Mulyadi. (2011). Sitem akuntansi dan Upah. Jakarta: Salemba Empat.

Prasetyo, dkk. (2013). Pengrauh Konsep Diri dan Kedisiplinan Terhadap Prestasi Belajar Jurusan Teknik Audio di SMK Muhammadiyah 3 Yogyakarta. Yogyakarta: Universitas Negeri Yogyakarta. Raharjo, B. dkk. (2012). Modul Pemrograman Web HTML, PHP \& MYSQL. Bandung: Modula.

Ruhul Amin. (2017). Rancang Bangun Sistem Informasi Penerimaan Siswa Baru Pada SMK Budhi Warman 1 Jakarta. Jurnal Ilmu Pengetahuan Dan Teknologi Komputer, 2(2), 113-121.

Sommerville, I. (2011). Software Engineering (Rekayasa Perangkat Lunak). Jakarta: Erlangga. Suherni, Rubiati, H. (2017). Aplikasi Pendaftaran Dan Penerimaan Siswa Baru Di Smk Negeri 1 Rupat Berbasis Web. Jurnal Informatika, Manajemen Dan Komputer, 9(2), 15-24.

Sutabri, T. (2012). Analisis Sistem Informasi. Yogyakarta: Andi.

Sutanta, E. (2011). Basis Data Dalam Tinjauan Konseptual. Yogyakarta: Andi Offset. 